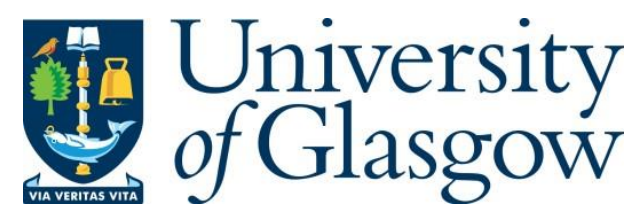

Chang, S., Zhang, Z., Cao, L., Ma, L., You, S. and Li, W. (2020) Co-gasification of digestate and lignite in a downdraft fixed bed gasifier: effect of temperature. Energy Conversion and Management, 213, 112798.

There may be differences between this version and the published version. You are advised to consult the publisher's version if you wish to cite from it.

http://eprints.gla.ac.uk/213199/

Deposited on: 1 April 2020

Enlighten - Research publications by members of the University of Glasgow http://eprints.gla.ac.uk 
Shengqiang Chang a,b, Zhikai Zhang a ${ }^{a}$ Lixia Cao a , Liqiang Ma ${ }^{b}$, Siming You ${ }^{\text {c, }}$, Wangliang $\mathrm{Li}^{\text {a, }}{ }^{*}$

a. The Key Laboratory of Green Process and Engineering, Institute of Process Engineering,

\title{
Co-gasification of digestate and lignite in a downdraft fixed bed gasifier: Effect of temperature
}

\author{
Chinese Academy of Sciences, 1 Zhongguancun, Haidian District, Beijing 100190, China \\ b. School of Chemical \& Environmental Engineering, China University of Mining \& \\ Technology (Beijing), Beijing 100083, China \\ c. Division of Systems, Power and Energy, James Watt School of Engineering, University of \\ Glasgow, UK, G12 8QQ \\ *Corresponding author: wlli@ipe.ac.cn (Wangliang Li); siming.you@glasgow.ac.uk (Siming \\ You)
}

Abstract: To improve energy efficiency and biomass utilization in the process of anaerobic digestion, co-gasification is considered as an effective method to post-treat anaerobic digestion residues. In this work, the effect of temperature $\left(650{ }^{\circ} \mathrm{C}, 750{ }^{\circ} \mathrm{C}\right.$, $850{ }^{\circ} \mathrm{C}$ and $950{ }^{\circ} \mathrm{C}$ ) on the co-gasification of digestate and lignite was thoroughly investigated in a downdraft fixed bed gasifier. The results showed that the increase of gasification temperature increased the gas yield and the lower heating value (LHV) of product gas. Physicochemical properties of biochar were characterized by physical adsorption analyzer, Fourier transform infrared spectroscopy (FT-IR), Raman spectroscopy and thermogravimetric analyzer (TG). It was shown that the average pore diameter increased in the range of $650^{\circ} \mathrm{C}$ to $950{ }^{\circ} \mathrm{C}$, while specific surface area and pore volume first increased from $650{ }^{\circ} \mathrm{C}$ to $850{ }^{\circ} \mathrm{C}$ and then decreased at $950{ }^{\circ} \mathrm{C}$. The Raman analysis of biochar indicated that small aromatic rings condensed to large aromatic ring and increased the content of $\mathrm{C}_{\text {aromatic }}-\mathrm{C}_{\text {alkyl }}$ and the crosslinking density at higher temperature. The variation of biochar properties at the higher temperature caused a decrease in the gasification reactivity. With the increase of temperature, the content of carbolic oil in the tar increased, but the contents of light oil, naphthalene oil and washing oil decreased. This study comprehensively analyzed the product properties and demonstrated the feasibility of co-gasification of digestate and lignite.

1 Keywords: co-gasification; lignite; digestate; downdraft fixed bed gasifier; biochar 


\begin{tabular}{|c|c|c|c|}
\hline \multicolumn{4}{|l|}{ Nomenclature } \\
\hline $\begin{array}{l}\text { Symbols } \\
\text { a }\end{array}$ & Slope of fitting straight line & $O$ & Ouantity adsorbed $\left[\mathrm{mL} \cdot \mathrm{o}^{-1}\right]$ \\
\hline $\mathrm{c}$ & Calculated by difference [\%] & $R_{09}$ & Reactivity index $\left[\mathrm{min}^{-1}\right]$ \\
\hline$C$ & Constant & $R^{2}$ & Correlation coefficient \\
\hline $\mathrm{C}_{\mathrm{CO}_{2}}$ & $\begin{array}{l}\mathrm{CO}_{2} \text { concentration in the gas } \\
{[\mathrm{vol} . \%]}\end{array}$ & $T$ & Temperature $\left[{ }^{\circ} \mathrm{C}\right]$ \\
\hline M & $\begin{array}{l}\text { Total mass of feedstock at each } \\
\text { run }[\mathrm{kg}]\end{array}$ & $t_{0.9}$ & $\begin{array}{l}\text { Gasification time when the } \\
\text { conversion of biochar reaches to } \\
0.9 \text { [min] }\end{array}$ \\
\hline $\begin{array}{l}\mathrm{G}, \mathrm{D}, \mathrm{S}, \mathrm{G}_{\mathrm{R}} \\
\mathrm{V}_{\mathrm{L}}, \mathrm{V}_{\mathrm{R}}\end{array}$ & $\begin{array}{l}\text { Peak names of Raman } \\
\text { spectroscopy }\end{array}$ & $V_{\text {gas }}$ & $\begin{array}{l}\text { Volume of } \mathrm{CO}, \mathrm{CO}_{2}, \mathrm{H}_{2}, \mathrm{CH}_{4} \text { and } \\
\mathrm{C}_{\mathrm{n}} \mathrm{H}_{\mathrm{m}}\left[\mathrm{Nm}^{3}\right]\end{array}$ \\
\hline $\mathrm{I}_{\mathrm{D}}, \mathrm{I}_{\mathrm{G}}, \mathrm{I}_{\mathrm{GR}}, \mathrm{I}_{\mathrm{VL}}$ & Peak area & $x_{n}$ & Molarity of all gases $(n=1,2 \cdots 7)$ \\
\hline$P / P_{0}$ & $\begin{array}{l}\text { Relative pressure of equilibrium } \\
\text { and saturation }\end{array}$ & $\alpha$ & $\begin{array}{l}\text { Content of impurity in } \mathrm{CO}_{2} \\
\text { cylinder [\%] }\end{array}$ \\
\hline$P_{0} / P$ & $\begin{array}{l}\text { Relative pressure of saturation } \\
\text { and equilibrium }\end{array}$ & & \\
\hline \multicolumn{4}{|l|}{ Abbreviations } \\
\hline $\mathrm{ad}$ & Air dry & GC-MS & $\begin{array}{l}\text { Gas chromatography-mass } \\
\text { spectrometer analyzer }\end{array}$ \\
\hline $\mathrm{AD}$ & Anaerobic digestion & HSAD & High-solid anaerobic digestion \\
\hline apd & Average pore dimeter $[\mathrm{nm}]$ & i.e. & Id est \\
\hline a.u. & Arbitrary unit & IUPAC & $\begin{array}{l}\text { International union of pure and } \\
\text { applied chemistry }\end{array}$ \\
\hline BET & Brunauer-Emmett-Teller & LHV & Lower heating value \\
\hline $\mathrm{C}=\mathrm{C}$ & Carbonyl & $\mathrm{N}$ & Nitrogen (monoatomic) \\
\hline $\mathrm{C}_{\text {aromatic }} \mathrm{C}_{\text {alkyl }}$ & $\begin{array}{l}\text { Carbon-carbon bond between } \\
\text { aromatic and alkyl }\end{array}$ & $\mathrm{Nm}^{3}$ & $\begin{array}{l}\text { Refers to } \mathrm{m}^{3} \text { at normal pressure } \\
\left(1.013 \times 10^{5} \mathrm{~Pa}\right) \text { and temperature } \\
\left(0^{\circ} \mathrm{C}\right)\end{array}$ \\
\hline $\mathrm{C}-\mathrm{H}$ & Carbon-hydrogen bond & $\mathrm{NO}_{\mathrm{x}}$ & Nitrogen oxide \\
\hline $\mathrm{CH}_{2}$ & Methylene & $\mathrm{O}$ & Oxygen (monoatomic) \\
\hline $\mathrm{CH}_{4}$ & Methane & $\mathrm{P}_{2} \mathrm{O}_{5}$ & Phosphorus pentoxide \\
\hline $\mathrm{CHx}$ & Alkyl & $\mathrm{S}$ & Sulfur (monoatomic) \\
\hline $\mathrm{C}_{\mathrm{n}} \mathrm{H}_{\mathrm{m}}$ & Hydrocarbon compounds & $\mathrm{SO}_{\mathrm{x}}$ & Sulfur-oxygen species \\
\hline Eq. & Equation & STP & Standard temperature and pressure \\
\hline FD & Fractal dimension & TCD & Thermal conductivity detector \\
\hline FHH & Frenkel-Halsey-Hill & TG & Thermogravimetric Analyzer \\
\hline F.S & Full scale & vol.\% & Volume percentage $[\%]$ \\
\hline FT-IR & $\begin{array}{l}\text { Fourier transform infrared } \\
\text { spectroscopy }\end{array}$ & wt. $\%$ & Weight percentage [\%] \\
\hline $\mathrm{GC}$ & Gas chromatography & & \\
\hline
\end{tabular}

\section{1. Introduction}

35 Because of the increasing energy consumption, depleting fossil fuel reserves, and 36 worsening environment related to the excessive use of fossil fuels, alternative sources 37 of renewable energies is receiving increasing attention [1]. The present concentration 38 of carbon dioxide $\left(\mathrm{CO}_{2}\right)$ in the atmosphere exceeds $400 \mathrm{ppm}$ and is proposed to reach $39530 \mathrm{ppm}$ and $650 \mathrm{ppm}$ in 2050 and 2100 , which will increase the global average 40 temperature by $2.0{ }^{\circ} \mathrm{C}-5.6{ }^{\circ} \mathrm{C}[2]$. 
High-solid anaerobic digestion (HSAD) is an effective method to battle the global warming by recovering energy from organic biomass [3]. However, the disposal of a by-product of HSAD, digestate, is challenging from the perspective of environment safety [4]. Digestate is a mixture of undigested biomass, sludge and manure from an anaerobic digestion (AD) system. In recent years, the development of biogas industry has caught the attention of the Chinese government. By the end of 2015, there were 110,975 biogas plants and 41.93 million household biogas digesters in China. The output of digestate increased significantly and rapidly, mainly used as soil fertilizer [5]. But the digestate is rich in hazardous materials, for instance, heavy metals, fungicides, pathogens, nitrogen compounds and trace herbicides, which may have latent hazards on human being, animals and crops [6]. The landfilling of digestate may lead to environmental pollution, land occupancy and greenhouse gas emissions. Accordingly, the resource reutilization of digestate becomes an urgent problem to be solved.

In the $\mathrm{AD}$ process, only part of the cellulose and hemicellulose has been hydrolyzed because of the rigid structure and resistance of non-biodegradable lignin, leading to a low energy conversion efficiency of approximately $33-50 \%[7,8]$. In the digestate, there are still many useful ingredients such as lignin. As biowaste, the digestate would be one promising alternate source to generate sustainable energy. In China, the projects where the digestate mixes with other combustibles from waste to

61 produce heat and power have been listed in the National Key Energy-Saving Low-Carbon Technology Promotion Catalogue (2017 Version, Low Carbon Section). Once this kind of technology is massively industrialized, the annual emission reduction of $\mathrm{CO}_{2}$ is expected to reach 1.85 million tons [9].

Gasification is a thermochemical technology that could convert the feedstock into the flammable gas (i.e. synthesis gas) effectively [10-12]. Chen et al. [7] conducted the air gasification of digestate in a downdraft fixed bed gasifier, and the results showed that the optimal lower heating value of product gas was $4.78 \mathrm{MJ} \cdot \mathrm{Nm}^{-3}$.

69 Yao et al. [13] proposed the co-gasification of woody chips and digestate, and the 70 optimal energy efficiency was $70.8 \%$ when the mass ratio of woody chips was $80 \mathrm{wt} . \%$ 71 and the moisture content of digestate was $30 \mathrm{wt} . \%$. Although the gasification of 72 digestate can reduce the volume of waste to be landfilled, kill the germs and 73 immobilize the toxic metals in the inorganic matrix [14], it is facing several 
74 challenges, such as low caloric value gas and low gasification efficiency, preventing the wide application of the technology.

Over the past decades, the low energy efficiency and significant air pollution of coal combustion limited its application for heat and energy production [15]. Predictably, the coal will continue to be the main energy source despite the fact that the China's energy structure is changing for the next several years [16, 17]. Seeking efficient and clean utilization of coal appears to be one of the main research focuses.

81 The co-gasification of biomass and coal has been widely investigated owing to its high energy conversion efficiency, remarkable economy benefits and operational stability. The co-gasification of biomass and coal can suppress the generation of $\mathrm{SO}_{\mathrm{x}}$ and $\mathrm{NO}_{\mathrm{x}}$ and cut the greenhouse gas emission [14, 18, 19]. Besides, the addition of coal in the mixture will make up the seasonal supply of biomass (e.g. digestate). Thengane et al. [20] used air as the gasification agent in the downdraft gasifier to deal with the garden waste pellets and coal. The LHV of gas reached to $3.05 \mathrm{MJ} \cdot \mathrm{Nm}^{-3}$ at biomass ratio 75 wt.\%. Wu et al. [21] added $50 \mathrm{wt} . \%$ coal into wheat straw, and the highest LHV of combustible gas achieved 14.21 $\mathrm{MJ} \cdot \mathrm{Nm}^{-3}$ in entrained flow bed with the preheating of gasification agent, which suggested that feeding the gasifier a combination of different fuels have synergy between their products and intermediates. Meanwhile, the co-gasification of different fuels will lead to maximize the performance, to reduce the carbon losses and to increase the energy content of syngas. However, the co-gasification of digestate and lignite has been rarely studied while it has the potential to bridge $\mathrm{AD}$ and gasification for high-efficient hybrid system development [22].

The co-gasification characteristics of biomass and coal is closely related to the reactor type and the operational conditions, such as temperature, gasification agent, mass ratios, etc [23]. Among them, the gasification temperature remarkably affected the release of volatiles from raw material and the gasification behaviors between the

101 gasification agent and biochar. Cortazar et al. [24] found that the gasification 102 temperature played a positive role in the improvement of gas yield and the tar removal. 103 Meanwhile, comparing with other gasifiers, the fixed bed would be more easily 104 controlled and more suitable to the co-gasification of biomass and coal. The fixed bed 105 can promote the intimate contact between raw material particles and provide 106 sufficient residence time. In terms of the downdraft fixed bed, the reduction zone is 
107 where the gasification occurs. The coal can provide more stable reaction temperature 108 for the co-gasification in the reduction zone. Moreover, the relatively slow thermal 109 conversion process may enhance the tar cracking [25]. Collot et al. [26] studied the 110 effect of reactor types on the co-gasification of biomass and coal finding that the tar 111 cracking occurred in the fixed bed. Li et al. [22] studied the effects of mixing methods 112 and the kinetics of the co-gasification of digestate and lignite, stating that the 113 synergistic interaction was the most remarkable when the anaerobic digestion 114 treatment time of biomass was 40 days. However, the effect of temperature on the 115 co-gasification behavior of digestate and lignite was seldom reported.

116 Therefore, the main objective of this study was to study the effect of temperature $117\left(650{ }^{\circ} \mathrm{C}, 750{ }^{\circ} \mathrm{C}, 850^{\circ} \mathrm{C}\right.$ and $\left.950{ }^{\circ} \mathrm{C}\right)$ on the co-gasification behavior of digestate and 118 lignite by analyzing co-gasification products comprehensively.

\section{2. Materials and methods}

\subsection{Materials}

The digestate was collected from the high solid anaerobic digestion of corn straw,

122 sludge and cattle manure. The coal was selected from the Xiaolongtan lignite. Prior to 123 the experiments, the samples were dried at $105^{\circ} \mathrm{C}$ until constant weight and pulverized 124 to below 150 mesh in a grinder. The ultimate analysis and proximate analysis of lignite 125 and digestate have been published in our previous study, as shown in Table 1 [22].

126 Table 1 Ultimate analysis and proximate analysis of lignite and digestate [22].

\begin{tabular}{ccccccccc}
\hline & \multicolumn{3}{c}{ Ultimate analysis } & $(\mathrm{wt} \%, \mathrm{ad})$ & \multicolumn{3}{c}{ Proximate analysis $(\mathrm{wt} \%, \mathrm{~d})$} \\
\cline { 2 - 9 } & $\mathrm{C}$ & $\mathrm{H}$ & $\mathrm{N}$ & $\mathrm{S}$ & $\mathrm{O}^{\mathrm{c}}$ & Volatile matter & Ash & Fixed carbon \\
\hline Lignite & 52.04 & 4.66 & 1.48 & 1.31 & 25.92 & 54.01 & 12.09 & 33.89 \\
Digestate & 29.64 & 3.61 & 2.38 & 0.54 & 20.31 & 47.75 & 41.48 & 10.77 \\
\hline
\end{tabular}

127 c: Calculated by difference.

\subsection{Gasification experiment set-up}

129 The experiments were conducted in a lab-scale downdraft fixed bed gasifier. Fig. 1 130 is the main process flow chart of digestate and lignite co-gasification in $\mathrm{CO}_{2}$ [22]. The 131 lab-scale downdraft fixed bed gasifier system contains a carrier gas system, electric 132 heating furnaces, a downdraft reactor and gas detection system. The downdraft reactor 133 contains a quartz tube, electric heating furnace and thermocouples. Wrapped by the 134 electric heating furnace, the quartz tube is $600 \mathrm{~mm}$ high and has an internal diameter of $13535 \mathrm{~mm}$. In the middle of the quartz tube, there is a distributor plate where the 
feedstock stored in the crucible is gasified in $\mathrm{CO}_{2}$.

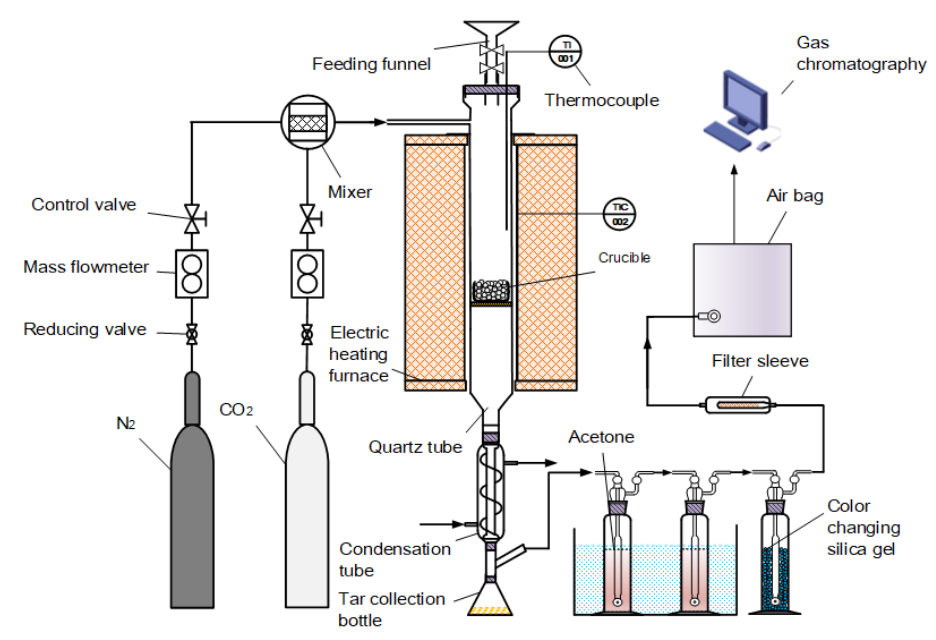

(a)

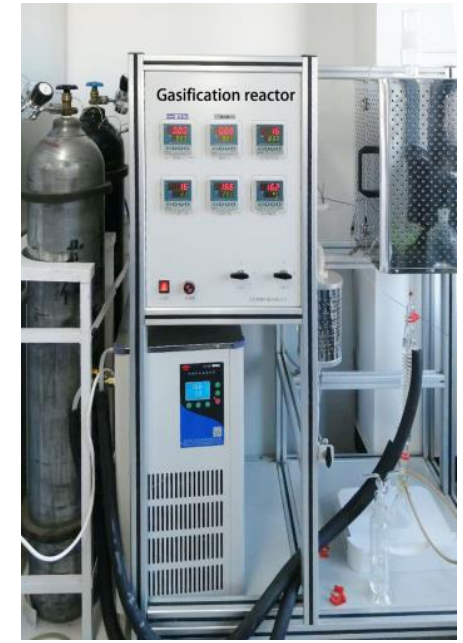

(b)

Fig. 1. (a) Flow chart of the gasification system, (b) real picture of the system, for the co-gasification of digestate and lignite.

The digestate and the lignite were manually mixed with the mass ratio $1: 1$ by mortar for complete blending. For each run, $2.00 \pm 0.01 \mathrm{~g}$ of feedstock was loaded into the crucible in the gasifier. Before starting up, pure $\mathrm{CO}_{2}(99.99 \%)$ was preloaded at a flow rate of $1000 \mathrm{~mL} \cdot \mathrm{min}^{-1}$ for $10 \mathrm{~min}$. Then, the flow rate of pure $\mathrm{CO}_{2}$ was switched to $60 \mathrm{~mL} \cdot \mathrm{min}^{-1}$. The gas flowmeter produced from Beijing Sevenstar Electronics Co.,Ltd., was used to control the $\mathrm{CO}_{2}$ gas flow. The scope of the flowmeter ranges from $0 \mathrm{~L} \cdot \mathrm{min}^{-1}$ to $2.0 \mathrm{~L} \cdot \mathrm{min}^{-1}$. The repeatability accuracy of the selected flowmeter is $\pm 0.2 \%$ F.S, namely $\pm 4 \mathrm{~mL}$ error. Maximum working pressure is $1.0 \mathrm{MPa}$. Before each run, the $\mathrm{CO}_{2}$ gas flow rate was calibrated by the soap-membrane flowmeter to guarantee that the $\mathrm{CO}_{2}$ gas flowmeter properly operated. The downdraft gasifier was heated from the room temperature to the target temperature at a heating rate of 50 ${ }^{\circ} \mathrm{C} \cdot \mathrm{min}^{-1}$, and then, the temperature remained constant. The $\mathrm{K}$-type thermocouple was selected to measure the temperature in the reactor and electric heating furnace in the range of $0{ }^{\circ} \mathrm{C}$ to $1300{ }^{\circ} \mathrm{C}$. The maximum allowable error was $\pm 0.4 \%$ of the measured temperature $\left(375{ }^{\circ} \mathrm{C}-1000{ }^{\circ} \mathrm{C}\right)$. The gas from the reactor passed through the vertical condensation tube, the ice-baths of acetone, silica gel and the filter to remove the tar, water and small particle impurities. The tar-free dry gas was collected in a gas bag and analyzed with gas chromatography to detect the proportion of each component. In this study, the gasification process proceeded for $46 \mathrm{~min}$. The total reaction time in 
reactor was identical and the properties of gasification products collected at the same time can be compared meaningfully. Then pure $\mathrm{CO}_{2}$ was switched to pure $\mathrm{N}_{2}$ $(99.99 \%)$ at a flow rate of $1000 \mathrm{~mL} \cdot \mathrm{min}^{-1}$ until the temperature in the gasifier dropped to room temperature. The reaction temperatures were chosen as $650{ }^{\circ} \mathrm{C}, 750$ ${ }^{\circ} \mathrm{C}, 850^{\circ} \mathrm{C}$ and $950^{\circ} \mathrm{C}$, respectively. The experiment was repeated three times for each run.

\subsection{Analytical methods}

The gas chromatography (Inficon, Micro GC 3000) was equipped with thermal conductivity detector (TCD) to analyze the product gas by external standard method. Back flushing was used as the method of injection gas. The injector temperature and transfer line temperature were $90{ }^{\circ} \mathrm{C}$. The first chromatographic column was $5 \mathrm{~A}$ molecular sieve and the column temperature was $80^{\circ} \mathrm{C}$, which was used to detect the $\mathrm{H}_{2}, \mathrm{CO}$ and $\mathrm{CH}_{4}$. Pure argon (99.999\%) was selected as carrier gas. The second chromatographic column was Plot Q and the column temperature was $60{ }^{\circ} \mathrm{C}$, which was used to detect the hydrocarbons gas $\left(\mathrm{C}_{n} \mathrm{H}_{m}, \mathrm{n}<4\right)$. The third chromatographic column was Plot $\mathrm{U}$ and the column temperature was $80{ }^{\circ} \mathrm{C}$, which was used to detect the $\mathrm{CO}_{2}$. Pure helium (99.999\%) was used as carrier gas of the subsequent two chromatographic columns. The dry gas $\mathrm{LHV}\left(\mathrm{MJ} \cdot \mathrm{Nm}^{-3}\right)$ and $\mathrm{CO}_{2}$ conversion was defined as follows [27, 28]:

$$
\mathrm{LHV}=\left(\mathrm{CO} \times 12600+\mathrm{H}_{2} \times 10794+\mathrm{CH}_{4} \times 35868+\mathrm{C}_{\mathrm{n}} \mathrm{H}_{\mathrm{m}} \times 63546\right) / 10^{5}
$$

where $\mathrm{CO}, \mathrm{H}_{2}, \mathrm{CH}_{4}, \mathrm{C}_{\mathrm{n}} \mathrm{H}_{\mathrm{m}}$ are the concentrations of the product gas, vol.\%.

$$
\mathrm{CO}_{2} \text { conversion }=100 \times\left(100-\alpha-C_{\mathrm{CO}_{2}}\right) /(100-\alpha) /\left(100+C_{\mathrm{CO}_{2}}\right)
$$

Where $\alpha$ is the content of impurity in $\mathrm{CO}_{2}$ cylinder, $0.01 \%, C_{C_{2}}$ is the $\mathrm{CO}_{2}$ concentration in the gas, vol. $\%$.

The yield of product gas $\left(\mathrm{Nm}^{3} \cdot \mathrm{kg}^{-1}\right)$ was defined as follows [13, 22, 29]:

$$
\text { Yield }=V_{\text {gas }} / M
$$

where $V_{\text {gas }}$ is the volume of $\mathrm{CO}, \mathrm{CO}_{2}, \mathrm{H}_{2}, \mathrm{CH}_{4}$ and $\mathrm{C}_{\mathrm{n}} \mathrm{H}_{\mathrm{m}}, \mathrm{Nm}^{3}, M$ is the total mass of feedstock at each run, $\mathrm{kg}$.

Nitrogen adsorption experiments (temperature, $77 \mathrm{~K}$ ) were carried out to characterize the biochar collected under different temperatures with a physical adsorption analyzer (Micromeritics, ASAP 2020HD88, America). Before the nitrogen adsorption experiments, all the biochar samples were degassed for $8 \mathrm{~h}$ at $200{ }^{\circ} \mathrm{C}$ under 
vacuum. The surface area and average pore diameter (apd) of biochar samples were measured using BET (Brunauer-Emmett-Teller). The pore volume was calculated from the single point desorption total pore volume of pores. The organ functional groups of biochar samples were identified by Fourier transform infrared spectroscopy (FT-IR, Bruker, T27, Germany) at wave lengths ranging from $400 \mathrm{~cm}^{-1}$ to $4000 \mathrm{~cm}^{-1}$. Each sample was scanned 32 times, with a resolution of $4 \mathrm{~cm}^{-1}$. Prior to analysis, per $1 \mathrm{mg}$ samples were mixed with per $100 \mathrm{mg} \mathrm{KBr}$ powder. The sample-powder mixture was reground by mortar and pestle homogeneously. Pellets were created using 70-80 $\mathrm{mg}$ of powder in a pellet press at $10 \mathrm{MPa}$ of pressure. Besides, the evolution of carbon structure was characterized by the Raman spectrum (Horiba Scientific, LabRAM HP

203 Evolution, Janpan). The Raman spectra from $1800 \mathrm{~cm}^{-1}$ to $800 \mathrm{~cm}^{-1}$ were analyzed 204 through peak fitting using Origin software (version 9.0) with nine Gaussian bands 205 combining the work of $\mathrm{Li}$ et al. [30] and the actual conditions in this article. The gasification reactivity of the biochar was investigated by a thermogravimetric analyzer (Setaram Labsys Evo, Lyon, Rhône Province, France) in $\mathrm{CO}_{2}$ adopting the non-isothermal route. About $5.0 \pm 0.2 \mathrm{mg}$ biochar was put into the crucible. The reaction temperature was risen from room temperature to $950{ }^{\circ} \mathrm{C}$ at $15{ }^{\circ} \mathrm{C} \cdot \mathrm{min}^{-1}$ and kept the constant temperature for $30 \mathrm{~min}$. The gasification reactivity of biochar was quantitated by the reactivity index $\left(R_{0.9}\right)$ as follows [31]:

$$
\mathrm{R}_{0.9}=0.9 / \mathrm{t}_{0.9}
$$
where $\mathrm{t}_{0.9}$ is the gasification time when the conversion of biochar reaches to 0.9 .

The fractal theory was used to characterize the unformed materials. The degree of surface irregularity can be quantified by the surface fractal dimension (FD) which ranges from 2 to 3 [32]. Based on the fractal version of the Frenkel-Halsey-Hill

217 (FHH) equation of multilayer adsorption, the values of surface fractal dimension can 218 be calculated through the single nitrogen adsorption isotherm [33, 34].

$$
\ln Q=\mathrm{a} \cdot \ln \left(\ln \left(P_{0} / P\right)\right)+C
$$

220 where $Q$ is the quantity adsorbed, $P_{0} / P$ is the relative pressure of saturation and 221 equilibrium, $C$ is a constant. Suppose $\mathrm{Y}$ is $\ln Q$ and $\mathrm{Y}=\mathrm{a} x+\mathrm{b}$. The parameter a is the 222 slope of fitting straight line. The surface fractal dimension of biochar is determined by 223 the coefficient a as follows:

$$
\mathrm{FD}=3+\mathrm{a}
$$

225 The analysis of the tar collected in the condensation system was carried out by a 
gas chromatography-mass spectrometer analyzer (GC-MS, QP 2010 Ultra, Shimadzu,

227 Japan). Helium (99.999 \%) was used as carrier gas in gas chromatography module and carrier gas flow rate was $1.2 \mathrm{~mL} \cdot \mathrm{min}^{-1}$. Split ratio was 49:1. The chromatographic column was $30 \mathrm{~m}$ RTX-5MS quartz capillary column. The inner diameter was 0.25 $\mathrm{mm}$ and film thickness was $0.25 \mu \mathrm{m}$. The temperature of ion source was $200{ }^{\circ} \mathrm{C}$ and

231 the scan range of mass to charge ratio was from 20 to 900 amu. Additionally, the tar was fractionated by a simulated distillation instrumentation (Agilent 7890A, America) according to the ASTM-D2887-01a standard. The column was stainless steel. The diameter of column was $0.53 \mathrm{~mm}$ and the length was $10 \mathrm{~m}$, which was designed by Sinopec Research Institute of Petroleum Processing in China.

\subsection{Reactions during gasification in $\mathrm{CO}_{2}$ atmosphere}

The thermal conversion behavior and the possible reactions of digestate and lignite under the $\mathrm{CO}_{2}$ atmosphere in the fixed bed reactor are shown as follows. Eq. (7) shows the overall gasification reaction of digestate and lignite in the $\mathrm{CO}_{2}$ atmosphere. The Boudouard reaction is presented in Eq. (8). The solid biochar gasification reactions processes are shown in Eq. (9) and Eq. (10). The homogeneous volatile reactions which are the piece of secondary reactions changing the evolved volatiles compositions are shown in Eq. (11) and Eq. (12) is the water-gas shift reaction. The tar gasification reactions and the tar cracking are presented in Eq. (13) and Eq. (14), respectively $[35,36]$. The tar contained hundreds of chemical compounds, such as aromatic compounds with single to five rings, polycyclic aromatic hydrocarbons (PAHs), and some oxygen-containing hydrocarbons. The chemical formula cannot represent the characterization of tar completely. Therefore, tar was used in the formula (7), (13) and (14) directly.

Digestate + Lignite $+x_{1} \mathrm{CO}_{2} \rightarrow x_{2} \mathrm{H}_{2}+x_{3} \mathrm{CO}+x_{4} \mathrm{CO}_{2}+x_{5} \mathrm{CH}_{4}+x_{6} \mathrm{C}_{\mathrm{n}} \mathrm{H}_{\mathrm{m}}+x_{7} \mathrm{H}_{2} \mathrm{O}+\mathrm{Char}+$ Tar

252 where $x_{1}, x_{2}, x_{3}, x_{4}, x_{5}, x_{6}$ and $x_{7}$ is the molarity of all gases.

$253 \mathrm{C}+\mathrm{CO}_{2} \leftrightarrow 2 \mathrm{CO}$

$254 \mathrm{C}+2 \mathrm{H}_{2} \rightarrow \mathrm{CH}_{4}$

255

256
$\mathrm{C}+\mathrm{H}_{2} \mathrm{O} \rightarrow \mathrm{CO}+\mathrm{H}_{2}$

$\mathrm{CO}+3 \mathrm{H}_{2} \leftrightarrow \mathrm{CH}_{4}+\mathrm{H}_{2} \mathrm{O}$

$$
\Delta \mathrm{H}=+172 \mathrm{~kJ} \cdot \mathrm{mol}^{-1}
$$$$
\Delta \mathrm{H}=-75 \mathrm{~kJ} \cdot \mathrm{mol}^{-1}
$$$$
\Delta \mathrm{H}=+131 \mathrm{~kJ} \cdot \mathrm{mol}^{-1}
$$$$
\Delta \mathrm{H}=-206 \mathrm{~kJ} \cdot \mathrm{mol}^{-1}
$$ 
$258 \mathrm{Tar}+\mathrm{CO}_{2} \rightarrow \mathrm{CO}+\mathrm{H}_{2}$

$\Delta \mathrm{H}=+980 \sim+3112 \mathrm{~kJ} \cdot \mathrm{mol}^{-1}$

259

$\mathrm{Tar} \rightarrow \mathrm{CH}_{4}+\mathrm{H}_{2}+\mathrm{H}_{2} \mathrm{O}+\mathrm{C}_{\mathrm{n}} \mathrm{H}_{\mathrm{m}}$

$\Delta \mathrm{H}>0$

\section{Results and discussion}

\subsection{Gas composition}

The effect of reaction temperature on gas composition was conducted at $650{ }^{\circ} \mathrm{C}$, $750{ }^{\circ} \mathrm{C}, 850{ }^{\circ} \mathrm{C}$ and $950{ }^{\circ} \mathrm{C}$ with the mass ratio $1: 1$. As shown in Fig. 2a, the temperature played a crucial role in the $\mathrm{CO}_{2}$ gasification performance and had a significant influence on the gas composition. The main components of the gas were CO and $\mathrm{CO}_{2} . \mathrm{H}_{2}, \mathrm{CH}_{4}$ and hydrocarbon compounds $\left(\mathrm{C}_{\mathrm{n}} \mathrm{H}_{\mathrm{m}}\right)$ were also observed. With the increase of gasification temperature, the $\mathrm{CO}$ content and the $\mathrm{CO}_{2}$ conversion increased obviously, due to the thermodynamic equilibrium enhancement of Eqs. (8) and (13). It was also related to equilibrium of the water-gas shift reaction as shown in Eq. (12).

The content of $\mathrm{C}_{\mathrm{n}} \mathrm{H}_{\mathrm{m}}$ was very low. Therefore, the content of $\mathrm{CH}_{4}$ was similar to the total content of $\mathrm{C}_{n} \mathrm{H}_{m}$. In Fig. 2, the red curve of $\mathrm{CH}_{4}$ was overlapped with cyan curve of $\mathrm{C}_{\mathrm{n}} \mathrm{H}_{\mathrm{m}}$. Meanwhile, the content of $\mathrm{CH}_{4}$ decreased slightly with the increase of temperature. The main reason for the decrease of $\mathrm{CH}_{4}$ content in the product gas is the increasing proportion of gasification gas and the decreasing proportion of pyrolysis gas. Another reason was attributed to the thermal decomposition of methane at the temperature of $700{ }^{\circ} \mathrm{C}[37]$.

$$
\mathrm{CH}_{4} \rightarrow \mathrm{C}+2 \mathrm{H}_{2} \quad \Delta \mathrm{H}=+74.8 \mathrm{~kJ} \cdot \mathrm{mol}^{-1}
$$

In Fig. 2b, the gas yield increased with the increase of gasification temperature. On the one hand, the tar as the primary gasification product was further cracked into gas at the higher temperature. Besides, the lignite was featured with the high ratios of heavy aromatic to aliphatic, highly ordered carbon fraction and high fixed carbon content [38]. The increase of temperature can activate the carbon atom and break the carbon chain in the aromatic ring rapidly, reacting with gasification agent- $\mathrm{CO}_{2}$ to produce gas. Thirdly, in the co-gasification process of digestate and lignite at $\mathrm{CO}_{2}$ atmosphere, the reduction of $\mathrm{CO}_{2}$ is an endothermic reaction. The increase of temperature was beneficial to the shift of reaction equilibrium towards the products. However, the $\mathrm{CO}_{2}$ yield increased firstly and then decreased gradually, which was due to the fact that the increase of temperature promoted the reaction-Eq. (7) and more $\mathrm{CO}_{2}$ 
was consumed in the gasification reaction-Eq. (8). When the consumption rate of $\mathrm{CO}_{2}$ was faster than the generation rate, the $\mathrm{CO}_{2}$ yield declined. The LHV of gas increased

291 with the increase of temperature. The $\mathrm{CO}$ content and $\mathrm{CO}_{2}$ conversion followed the 292 same trend. When the temperature was $950{ }^{\circ} \mathrm{C}$, the LHV of gas was the highest, 6.52 $293 \mathrm{MJ} \cdot \mathrm{Nm}^{-3}$, and nearly twice that of the $650^{\circ} \mathrm{C}$.

294 The gasification performances can be significantly influenced by the metal 295 contents such as $\mathrm{Na}, \mathrm{K}, \mathrm{Ca}, \mathrm{Fe}$, etc. The rate of catalytic gasification significantly increased in the presence of alkali and alkaline earth metals and transition metals in the char. The $\mathrm{CO}_{2}$ co-gasification performances showed its great potentials in enhancing the gasification reactivity, mitigating the problem of agglomeration and alleviating the greenhouse effect, through the utilization of ash from biomass wastes as catalyst [39, 40]. As shown in our previous study, the lignite and digestate all contained many alkali metals and alkaline earth metals [22]. It is reasonable to believe that the alkali metals and alkaline earth metals in the ash played an important role in co-gasification of lignite and digestate.
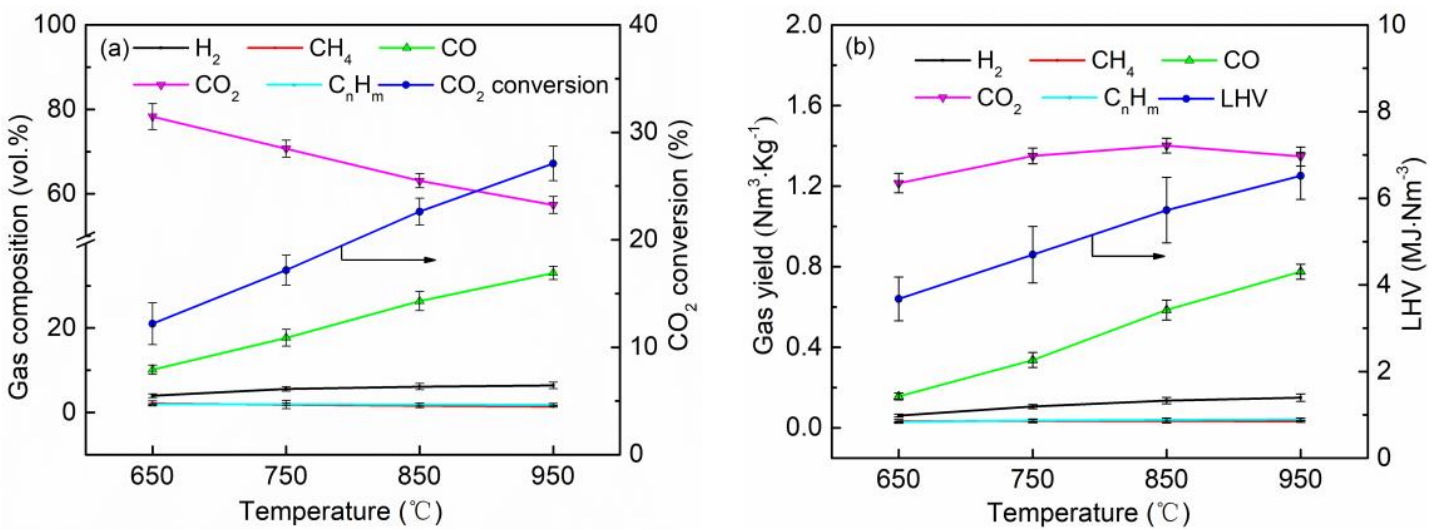

Fig. 2. Effect of temperature on the characteristics of product gas.

\subsection{Physicochemical properties of biochar}

\subsubsection{Textural structure of biochar}

The adsorption-desorption isotherms of biochar samples produced at different temperatures were illustrated in Fig. 3. According to the IUPAC classification, the

310 adsorption isotherm of biochar samples presented the reversed S-shape between type I

311 and type II, indicating that the pore characteristics of biochar samples were similar, 312 continuous and complicated after the different gasification temperatures treatment.

313 The nitrogen adsorption quantity reflects the adsorptive capacity of the biochar [32].

314 At extreme low pressure $\left(\mathrm{P} / \mathrm{P}_{0}<0.05\right)$, the adsorption quantities of biochar samples at 
different gasification temperatures $\left(650{ }^{\circ} \mathrm{C}, 750{ }^{\circ} \mathrm{C}, 850{ }^{\circ} \mathrm{C}\right.$, and $\left.950{ }^{\circ} \mathrm{C}\right)$ were 46.77 $\mathrm{mL} \cdot \mathrm{g}^{-1}, 61.94 \mathrm{~mL} \cdot \mathrm{g}^{-1}, 65.24 \mathrm{~mL} \cdot \mathrm{g}^{-1}$ and $41.15 \mathrm{~mL} \cdot \mathrm{g}^{-1}$, which indicated a large

317 number of micropores. Moreover, the amount of micropores increased from $650{ }^{\circ} \mathrm{C}$ to $318850{ }^{\circ} \mathrm{C}$ and decreased from $850{ }^{\circ} \mathrm{C}$ to $950{ }^{\circ} \mathrm{C}$ sharply. This revealed that the increase 319 of gasification temperature was in favor of the formation of micropores to a certain 320 extent because the higher temperature can not only promote the discharge of pyrolysis 321 products but also enhance $\mathrm{CO}_{2}$ gasification with the reactive sites. However, when the temperature rose to $950{ }^{\circ} \mathrm{C}$, the amount of micropores in the biochar samples was the lowest. The high temperature promoted the formation of mesopores and macropores by the aggregation of original micropores during gasification. The sintering effect that can seal off the part of the micropores was another factor which should not be ignored simultaneously [32]. Fu et al. [32] found the similar trend of biochar samples that the amount of micropores increased with the increase of temperature and then decreased. $\mathrm{Xu}$ [41] reported that the amount of micropores increased firstly and decreased sharply due to the breaking of the microporous structure. Li et al. [42] also found the similar results that the adsorption quantity of biochar increased from $500{ }^{\circ} \mathrm{C}$ to $800{ }^{\circ} \mathrm{C}$.

331 However, the quantity of adsorption decreased sharply when the temperature 332 increased from $800{ }^{\circ} \mathrm{C}$ to $900{ }^{\circ} \mathrm{C}$.

Table 2 Textural properties of the biochar samples.

\begin{tabular}{ccccc}
\hline $\mathrm{T},{ }^{\circ} \mathrm{C}$ & Specific surface area, $\mathrm{m}^{2} \cdot \mathrm{g}^{-1}$ & Pore volume, $\mathrm{cm}^{3} \cdot \mathrm{g}^{-1}$ & Average pore diameter, $\mathrm{nm}$ & FD \\
\hline 650 & 196.68 & 0.12 & 2.46 & 2.9155 \\
750 & 256.19 & 0.18 & 2.79 & 2.9118 \\
850 & 277.49 & 0.22 & 3.11 & 2.9004 \\
950 & 176.03 & 0.19 & 4.41 & 2.8072 \\
\hline
\end{tabular}

334 As shown in Table 2, the specific surface area of the biochar samples increased 335 from $650{ }^{\circ} \mathrm{C}$ to $850{ }^{\circ} \mathrm{C}$ and decreased from $850{ }^{\circ} \mathrm{C}$ to $950{ }^{\circ} \mathrm{C}$. Ping et al. [43] found 336 the variation of the specific surface area was mainly due to the formation and 337 breaking of micropores. In the medium pressure adsorption zone $\left(0.05<\mathrm{P} / \mathrm{P}_{0}<0.8\right)$, 338 the adsorption curves transformed from monolayer to multilayer adsorption and the 339 adsorption quantities from $650{ }^{\circ} \mathrm{C}$ to $950{ }^{\circ} \mathrm{C}$ were $13.94 \mathrm{~mL} \cdot \mathrm{g}^{-1}, 34.27 \mathrm{~mL} \cdot \mathrm{g}^{-1}, 51.39$ $340 \mathrm{~mL} \cdot \mathrm{g}^{-1}$ and $46.37 \mathrm{~mL} \cdot \mathrm{g}^{-1}$. The adsorption quantity increased with the increase of 341 temperature from $650{ }^{\circ} \mathrm{C}$ to $850{ }^{\circ} \mathrm{C}$, indicating that the amount of mesopores 342 increased. When the temperature increased from $850{ }^{\circ} \mathrm{C}$ to $950{ }^{\circ} \mathrm{C}$, the adsorption 343 quantity decreased showing that the amount of mesopores decreased. In the saturated 344 pressure zone $\left(0.9<\mathrm{P} / \mathrm{P}_{0}<0.995\right)$, the adsorption quantities from $650{ }^{\circ} \mathrm{C}$ to $950{ }^{\circ} \mathrm{C}$ 
were $17.57 \mathrm{~mL} \cdot \mathrm{g}^{-1}, 19.29 \mathrm{~mL} \cdot \mathrm{g}^{-1}, 22.90 \mathrm{~mL} \cdot \mathrm{g}^{-1}$, and $38.02 \mathrm{~mL} \cdot \mathrm{g}^{-1}$. The adsorption curves became steeper with the increase of temperature, indicating the capillary condensation appeared and the amount of macropores increased sharply. As the temperature increased, $\mathrm{CO}_{2}$ reacted with the carbon skeleton, leading to the formation of macropores rapidly by the aggregation of some original mesopores. Therefore, the amount of mesopores decreased when the temperature increased from $850{ }^{\circ} \mathrm{C}$ to $950{ }^{\circ} \mathrm{C}$. In Table 2 , the pore volume increased from $650{ }^{\circ} \mathrm{C}$ to $850{ }^{\circ} \mathrm{C}$ and then decreased from $850{ }^{\circ} \mathrm{C}$ to $950{ }^{\circ} \mathrm{C}$, while the average pore size increased from $650{ }^{\circ} \mathrm{C}$ to $950{ }^{\circ} \mathrm{C}$. The phenomenon that two measurements had different trends showed the pore length at $950{ }^{\circ} \mathrm{C}$ was shorter than that at $850{ }^{\circ} \mathrm{C}$, indicating that the erosion of the biochar surface through gasification in $\mathrm{CO}_{2}$ was promoted. The variation trend of pore volume was consistent with the change in amount of micropores and mesopores.

357 The formation and breaking of micropores and mesopores may be the reason that pore 358 volume increased firstly and then decreased.

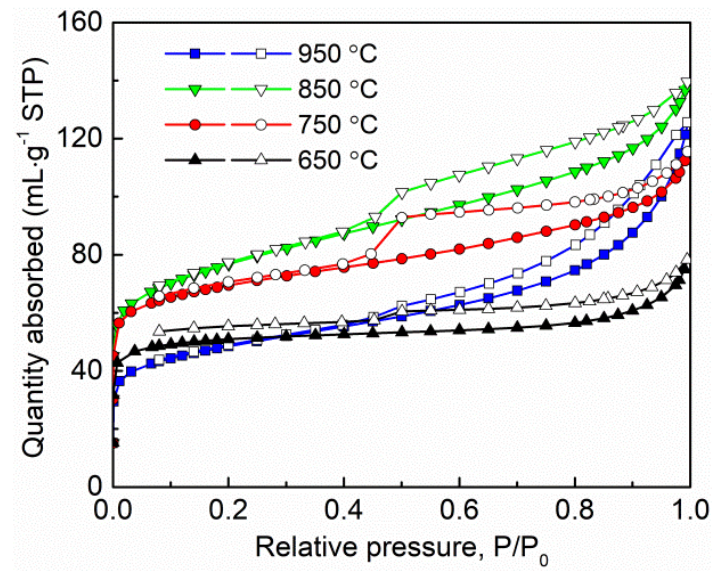

Fig. 3. Adsorption-desorption isotherm curves of the biochar samples.

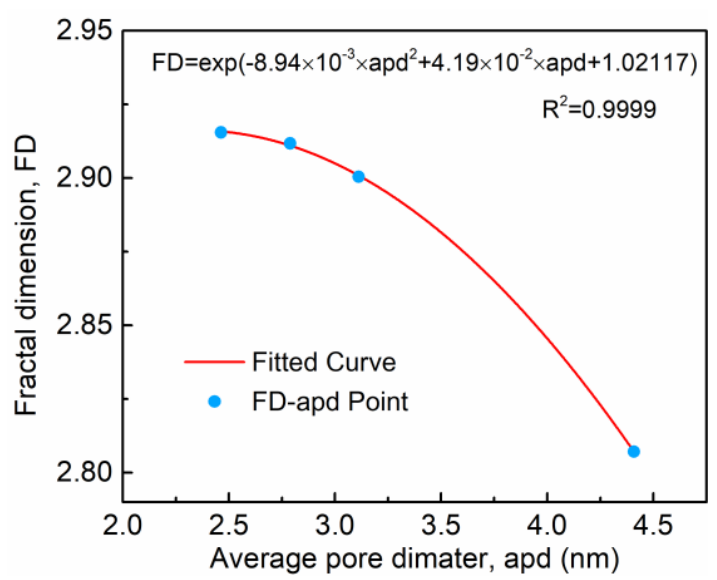

Fig. 4. Functional relationship between the average pore diameter and fractal dimension of biochar samples. 
The fractal dimension values of the co-gasification biochar samples were revealed in Table 2. The values of FD decreased with the increase of gasification temperature indicating the surface roughness of biochar would decrease under the action of the gasification agent- $\mathrm{CO}_{2}$. Curve fitting method was used to measure the functional relationship between average pore diameter and fractal dimension [32]. As shown in Fig. 4, it was clearly observed that there was an exponential relationship between the two variables as shown in the Eq. (16). The correlation coefficient $\mathrm{R}^{2}$ was 0.9999 , approximating to 1 , which can well describe the relationship of the two variables reasonably. The results of fractal dimension were valid when average pore diameter ranged from $2.46 \mathrm{~nm}$ to $4.41 \mathrm{~nm}$. The negative correlation was observed and was consistent with the results from $\mathrm{Fu}$ et al. [32] who found that the linear relationship between the average pore diameter and fractal dimension were based on the co-pyrolysis biochar samples. However, the above results were based on the co-gasification biochar samples. The gasification process made the evaluation of biochar more complicated and the exponential relationship can more accurately describe the two variables. As the average pore diameter increased, the FD decreased based on the function relationship providing further support for the conclusion that the sharp decrease of micropores and the increase of macropores at $950{ }^{\circ} \mathrm{C}$ promoted the growth of pore diameter and the reduction of pore length resulting in the decrease of surface roughness.

$$
\mathrm{FD}=\exp \left(-8.94 \times 10^{-3} \times \mathrm{apd}^{2}+4.19 \times 10^{-2} \times \mathrm{apd}+1.02117\right) \quad 2.46 \leq \mathrm{apd} \leq 4.41
$$

\subsubsection{FT-IR analysis of biochar}

Fig. 5 showed the FT-IR spectra of the biochar samples produced at different temperatures. It was evident that there were many functional groups such as aliphatic

$388 \mathrm{CH}_{2}\left(1,3000-2800 \mathrm{~cm}^{-1}\right)$, aromatic carbonyl $\left(2,1800-1400 \mathrm{~cm}^{-1}\right)$, ether bond (3, 389 1150-1085 $\left.\mathrm{cm}^{-1}\right)$, phosphate $\left(4,1150-950 \mathrm{~cm}^{-1}\right)$, and aromatic CHx out of plane (5, $\left.900-700 \mathrm{~cm}^{-1}\right)$ in the biochar $[41,44]$. The absorbance intensity can be used to compare the relative content difference among the functional groups of biochar produced at different gasification temperatures. The intensity of ether bond (1091 $\mathrm{cm}^{-1}$ ) decreased with the increase of temperature indicating that the ether bond broken

394 at the higher temperature [41]. The largest peaks at $985 \mathrm{~cm}^{-1}, 1042 \mathrm{~cm}^{-1}, 1120 \mathrm{~cm}^{-1}$

395 belonged to the phosphates, which covered the wavenumber from $900 \mathrm{~cm}^{-1}$ to 1250 $\mathrm{cm}^{-1}$ [44-48]. As shown in Li's study, the digestate ash contained the component $\mathrm{P}_{2} \mathrm{O}_{5}$ 
[22]. The ash relative contents in the biochar increased with the rise of gasification temperature due to the consumption of organic matter. The reason may be that the phosphate peaks became stronger and stronger with the increasing temperature.

400 Besides, the characteristic peaks representing the structure of aromatic $\mathrm{C}=\mathrm{C}$ (1620 $401 \mathrm{~cm}^{-1}, 1585 \mathrm{~cm}^{-1}, 1480 \mathrm{~cm}^{-1}, 1410 \mathrm{~cm}^{-1}$ ) became prominent, suggesting that the aromatization trend was more and more obvious [49, 50]. The intensity of aliphatic side chains methylene $\left(2923 \mathrm{~cm}^{-1}, 2852 \mathrm{~cm}^{-1}\right)$ decreased evidently with the increase of temperature from $650{ }^{\circ} \mathrm{C}$ to $950{ }^{\circ} \mathrm{C}$. Methylene was the form of aliphatic side chain in the biochar, and it mainly existed in long chain. In addition, it meant that the decompose of aliphatic compounds contained in digestate and lignite were gradually completed, forming methane or other organic gas as the rise of gasification temperature [51,52].

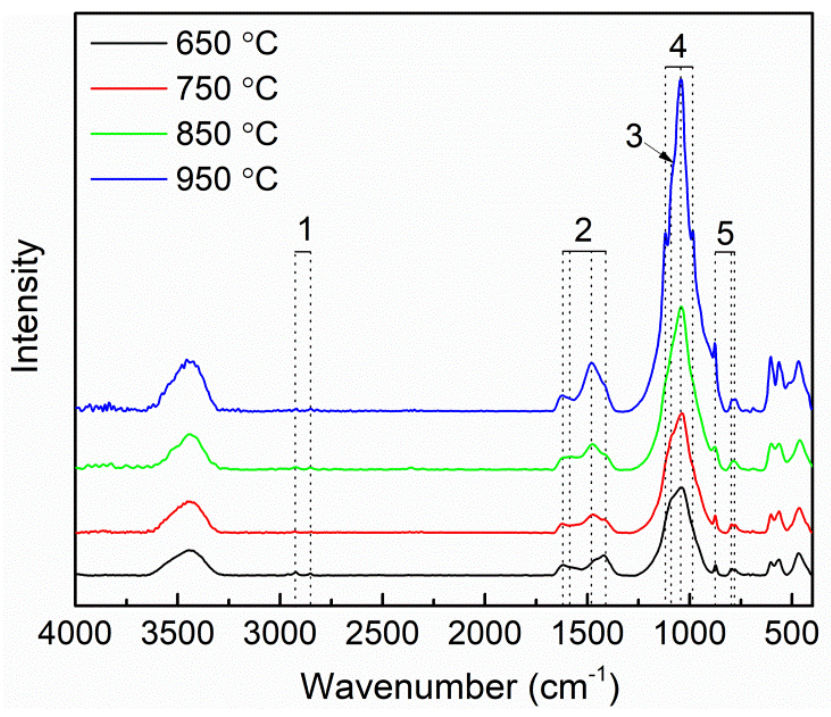

\subsubsection{Raman analysis of biochar}

414 The Raman spectroscopy has been widely used in investigating the structural 415 characteristics of biochar by calculating the intensity ratio among the different bands $416[30,53]$. Fig. 6 showed the parameters obtained from the Raman spectra of biochar 417 produced at different temperatures. The digestate and lignite were rich in the 418 O-containing functional groups and aliphatic structures, which were not likely to be 419 converted into graphite structures at around $900{ }^{\circ} \mathrm{C}[54,55]$. The $\mathrm{G}$ band and $\mathrm{D}$ band mainly represented the aromatic ring vibration and the aromatic ring

421 polycondensation with 6 or more polymerized aromatic rings instead of graphite and 
defect structures $[53,55]$. From Fig. 6a, it was clearly observed that the total peak areas decreased with the rise of gasification temperature, because the sensitive 424 aliphatic and oxygenated groups decomposed with the increase of temperature. In 425 addition, the increase of aromatic structure can increase the light absorptivity [53, 54, 426 56]. This was consistent with the FT-IR results. In Fig. 6b, the $\mathrm{I}_{\mathrm{D}} / \mathrm{I}_{\mathrm{G}}, \mathrm{I}_{\mathrm{D}} /\left(\mathrm{I}_{\mathrm{GR}}+\mathrm{IV}_{\mathrm{L}}+\mathrm{IV}_{\mathrm{R}}\right)$ 427 and $I_{S} / I_{G}$ band area ratios increased when the temperature increased. The increasing $428 \mathrm{I}_{\mathrm{D}} / \mathrm{I}_{\mathrm{G}}$ represented the growth in polycondensation of aromatic ring systems. The $\mathrm{G}_{\mathrm{R}}$, $429 V_{L}$ and $V_{R}$ bands deriving from the zone between the $D$ band and the $G$ band 430 represented the smaller aromatic ring systems and the semicircle breathing of 431 aromatic rings $[44,45,57,58]$. The $\mathrm{I}_{\mathrm{D}} /\left(\mathrm{I}_{\mathrm{GR}_{R}}+\mathrm{I}_{\mathrm{V}_{\mathrm{L}}}+\mathrm{IV}_{\mathrm{V}}\right)$ band area ratio is defined as the 432 relative content of the large ( $\geqslant 6$ rings) aromatic ring systems to the small ones(3-5 433 fused benzene rings) [57, 58]. The increasing $\mathrm{I}_{\mathrm{D}} /\left(\mathrm{I}_{\mathrm{GR}}+\mathrm{I}_{\mathrm{V}_{\mathrm{L}}}+\mathrm{I}_{\mathrm{V}_{\mathrm{R}}}\right)$ ratio indicated that 434 the small aromatic rings condensed to large aromatic ring systems as the temperature 435 rose. The $\mathrm{S}$ band mainly represented the $\mathrm{C}_{\text {aromatic }}-\mathrm{C}_{\text {alkyl }}$ and $\mathrm{C}-\mathrm{H}$ attached to the 436 aromatic rings and was used to measure the substituents and crosslinking density [30, 437 57]. The increasing $\mathrm{I}_{\mathrm{S}} / \mathrm{I}_{\mathrm{G}}$ band area ratio indicated the content of $\mathrm{C}_{\text {aromatic }}-\mathrm{C}_{\text {alkyl }}$ and the 438 crosslinking density increased with the rise of temperature [30].
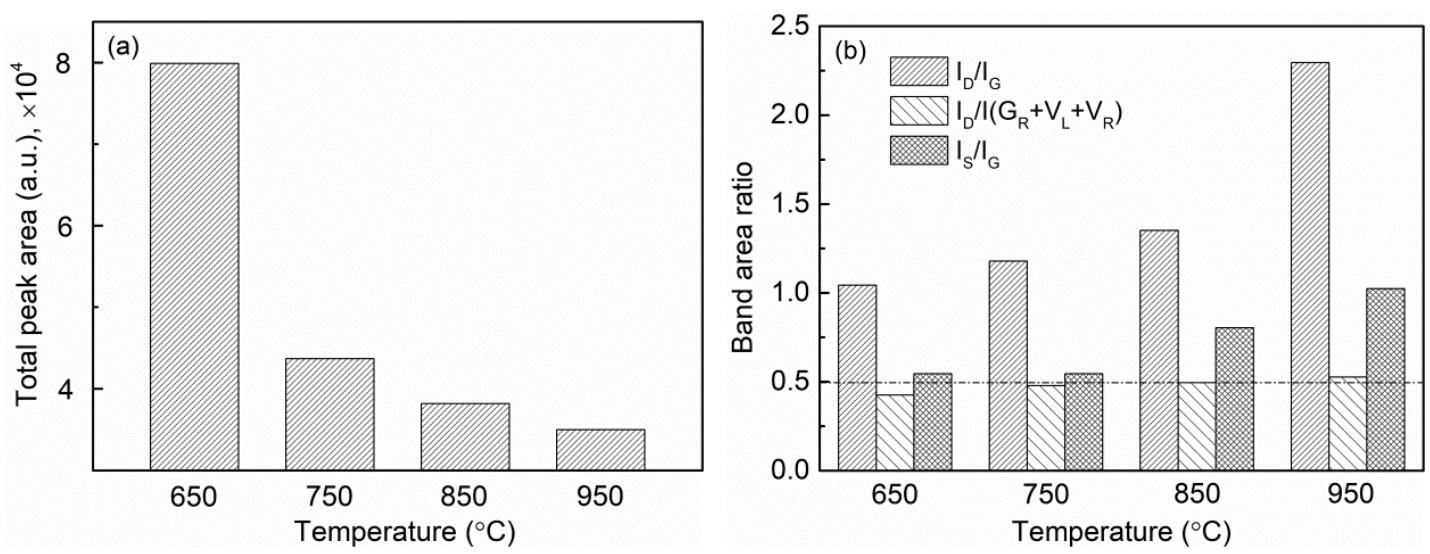

Fig. 6. Raman spectra of the biochar produced at different temperatures.

\subsubsection{Reactivity of biochar in $\mathrm{CO}_{2}$ gasification}

Fig. 7 showed the gasification conversion of biochar obtained at different temperatures in $\mathrm{CO}_{2}$. It was clearly observed that the conversion curves of biochar were quite similar. The char conversion started late at a high temperature of about $700{ }^{\circ} \mathrm{C}$ and completed around $63 \mathrm{~min}$ in the steam atmosphere. When the gasification

447 was operated at higher temperature, the char conversion started much later. Hu et al. 448 [59] investigated biochar conversion versus gasification time and found the initial 
gasification temperature was around $800{ }^{\circ} \mathrm{C}$ in the steam atmosphere. As shown in 450 Table 3, with the increase of gasification temperature from $650{ }^{\circ} \mathrm{C}$ to $950{ }^{\circ} \mathrm{C}$, the reaction reactivities decreased slightly from $0.0154 \mathrm{~min}^{-1}$ to $0.0148 \mathrm{~min}^{-1}$. The gasification reactivities of biochar presented the same trend that the reaction temperature affected the biochar characteristics, due to the fact that the erosion degree of biochar surface by $\mathrm{CO}_{2}$ was different at different temperatures. According to the

455 Section 3.2.1, a larger pore diameter was gradually formed on the surface of biochar.

456 More highly active components escaped, thus, reducing the activity of the biochar, and higher temperatures would promote the aggregation of minerals in the mixture, resulting in the diminishing of catalysis $[60,61]$. Another possible reason is that the aromatization degree of char may affect the reactivities [60,61]. According to the Section 3.2.3, more and more small aromatic rings condensed to large aromatic ring systems as the temperature rose, the thermal stability of which was higher. The broken of large aromatic ring structure by gasification agent $\mathrm{CO}_{2}$ needed much more energy.

463 Therefore, the reactivities of biochar decreased when produced at higher temperature.

464 Xu's $[60,61]$ study stated the same trend and concluded that there were many defects in the microcrystalline structure of char produced at low temperature, which was the active sites of gasification reaction. As the temperature increased, the number of active sites decreased and the reactivities of biochar declined.

468

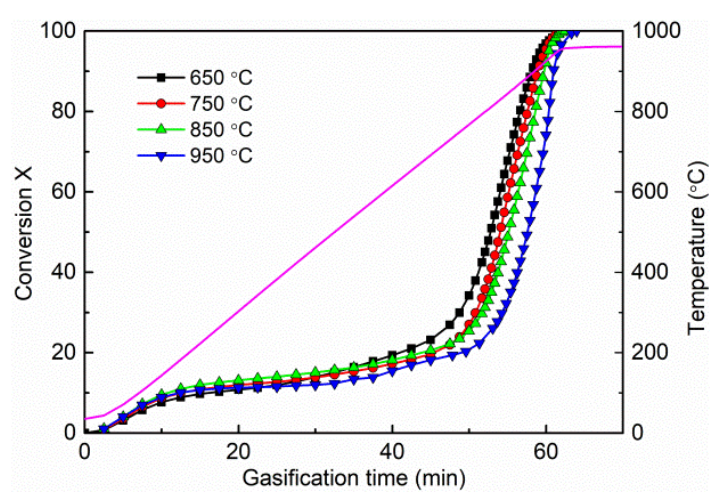

Fig. 7. Gasification conversion curves of biochar obtained from the $\mathrm{CO}_{2}$ co-gasification.

Table 3 Gasification reactivity index of biochar.

\begin{tabular}{cc}
\hline Temperature, ${ }^{\circ} \mathrm{C}$ & Gasification reactivity, $\min ^{-1}$ \\
\hline 650 & 0.0154 \\
750 & 0.0152 \\
850 & 0.0150 \\
950 & 0.0148
\end{tabular}


The components of tar analyzed by chromatography can be classified into the following groups: (a) alkane; (b) alkene; (c) aromatics; (d) others, with N, O and S

476 [60]. Fig. 8 showed the effect of temperature on the tar compositions. It was 477 noteworthy that the main composition of tar was aromatics and the contents of alkane and alkene were quite small. The content of alkane increased from $650{ }^{\circ} \mathrm{C}$ to $750{ }^{\circ} \mathrm{C}$ and decreased gradually with the rise of temperature because high temperature enhanced the hydrolysis reaction and production of alkane. In addition, the content of alkene increased because partial volatiles converted into alkene through polymerization at higher temperature. The overall trend of aromatics concentration increased with the increase of temperature. The properties of aromatics were inert and the reduction of other compounds resulted in the increase of aromatics content relatively.

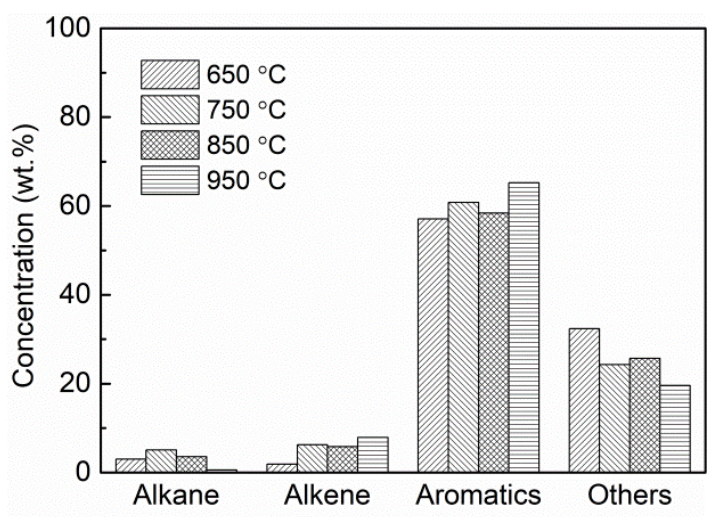

Fig. 8. Effect of temperature on the tar compositions. generally appeared as a dark brown organic liquid mixture with high viscosity and low fluidity, which was poorly soluble in water. The physical properties of tar were determined by the amount of aromatics and heterocyclic compounds. The aromatics had the characteristics of high molecular weight and was easy to condense in the gasification reactor with fly ash particles, fouling and plugging pipelines of the gasification reactor. In addition, various $\mathrm{N}$-heterocyclic and aromatics in the tar were toxic contaminants. If the contaminants were absorbed by the soil, surface water and groundwater, there will be a potential threat and a great challenge to the environment 

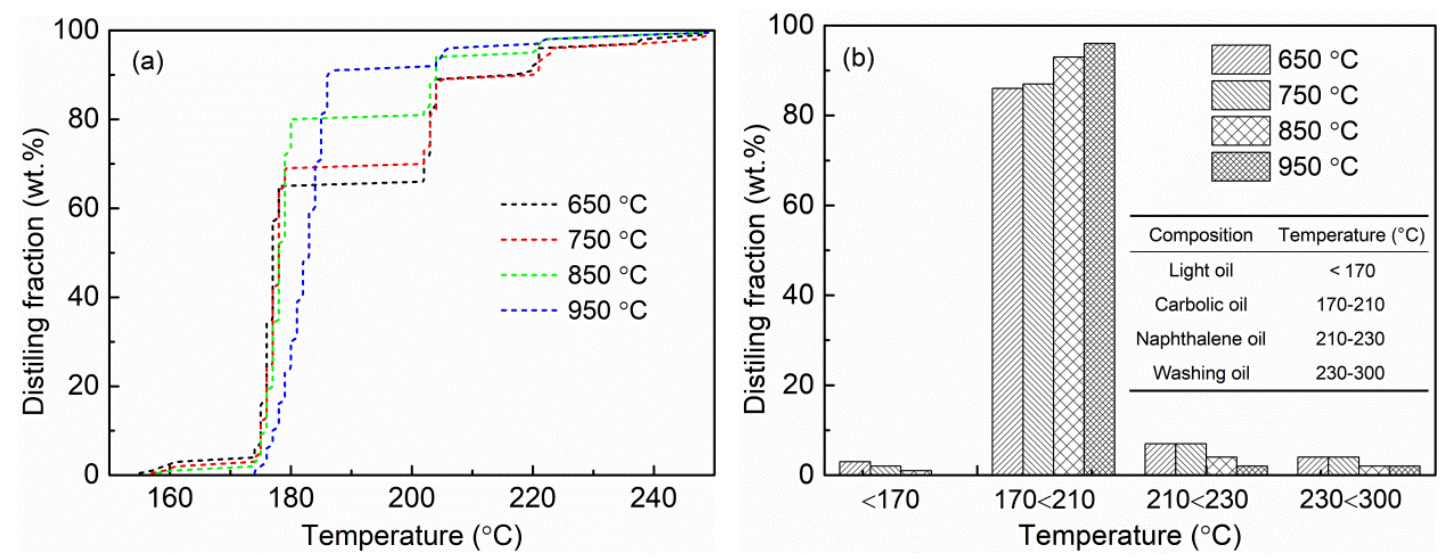

Fig. 9. Distillation fractions of tar produced from the co-gasification of digestate and lignite.

The simulated distillation can be used to analyze the fractional compositions of tar. Fig. 9 showed the distillation fractions of tar obtained from the co-gasification of digestate and lignite. In Fig. 9a, three big fractions in the tar grouped at the temperatures of $170{ }^{\circ} \mathrm{C}-190{ }^{\circ} \mathrm{C}, 200{ }^{\circ} \mathrm{C}-210{ }^{\circ} \mathrm{C}, 220{ }^{\circ} \mathrm{C}-250{ }^{\circ} \mathrm{C}$. The contents of the

508 fractions below $190{ }^{\circ} \mathrm{C}$ increased with the increase of gasification temperature, while 509 contents of the fractions between $190{ }^{\circ} \mathrm{C}$ and $250^{\circ} \mathrm{C}$ decreased evidently. It indicated that the increase of gasification temperature improved the cracking of tar, resulting in

511 the higher yield of gas, as shown in the Section 3.1. Fig. 9b compared the contents of 512 each distillation fraction given by the simulated distillation for the tar samples at 513 different gasification temperatures [63]. With the increase of temperature, the content 514 of carbolic oil increased obviously, but those of light oil, naphthalene oil and washing 515 oil decomposed and decreased gradually. It showed that the increase of temperature 516 promoted the secondary reaction of tar in fixed bed reactor. According to Xu' study, 517 the similar results of the pyrolysis tar of coal showed that the heavy tar decreased and 518 other oil contents increase slightly [60].

\section{Conclusions}

This study investigated the influence of temperature on co-gasification behavior

521 of digestate and lignite in a downdraft fixed bed gasifier. The gasification temperature

522 from $650{ }^{\circ} \mathrm{C}$ to $950{ }^{\circ} \mathrm{C}$ were tested by analyzing the characteristics of the product gas,

523 biochar and the tar. The major conclusions of this research were summarized as 524 below:

525 (1) The gasification temperature was beneficial for the increasing the gas yield 
and its $\mathrm{LHV}$ and improving the $\mathrm{CO}_{2}$ conversion.

(2) The effects of gasification temperature on the properties of the biochar were complicated. The increase of temperatures from $650{ }^{\circ} \mathrm{C}$ to $850{ }^{\circ} \mathrm{C}$ played a positive role in the formation of micropores. While, the sharp decrease of micropores and the formation of macropores occurred at $950{ }^{\circ} \mathrm{C}$. Increasing the gasification temperature caused the decrease of aliphatic side chains and a growth in size and number of aromatic ring systems. Besides, as the temperature rose, the gasification reactivity became weaker gradually because of the more and more large aromatic ring systems and the less active components.

(3) With the increase of gasification temperature, the content of carbolic oil obviously increased, while the light oil, naphthalene oil and washing oil decomposed and their contents decreased gradually. The increasing temperature promoted the secondary reaction of tar in fixed-bed reactor.

\section{Declaration of Competing Interest}

The authors declare that they have no known competing financial interests or personal relationships that could have appeared to influence the work reported in this paper.

\section{Acknowledgments}

This work was supported by the National Natural Science Foundation of China (No. 21878313) and Guizhou Key Technology Support Program ([2019]2839).

\section{References}

[1] Estrada CA, Melgar A, Pérez JF. Performance prediction of a decentralized power plant $(120 \mathrm{kWe})$ using a multi-particle model of a downdraft biomass gasification process. Energy Convers Manage 2019;181:258-71.

[2] Engo J. Decoupling analysis of $\mathrm{CO}_{2}$ emissions from transport sector in Cameroon. Sustain Cities Soc 2019;51:101732.

[3] Li W, Lu C, An G, Chang S. Comparison of alkali-buffering effects and co-digestion on high-solid anaerobic digestion of horticultural waste. Energ Fuel 2017;31(10):10990-7.

[4] Barbanera M, Pelosi C, Taddeid AR, Cotana F. Optimization of bio-oil production from solid digestate by microwave assisted liquefaction. Energy Convers Manage 2018;171:1263-72.

[5] National Development and Reform Commission. National 13th five-year development plan for rural biogas. 2017. Available at: http://www.gov.cn/xinwen/2017-02/10/content_5167076.htm 
[6] Cao Z, Jung D, Olszewski MP, Arauzo PJ, Kruse A. Hydrothermal carbonization of biogas digestate: Effect of digestate origin and process conditions. Waste Manage 2019;100:138-50.

[7] Chen G, Guo X, Cheng Z, Yan B, Dan Z, Ma W. Air gasification of biogas-derived digestate in a downdraft fixed bed gasifier. Waste Manage 2017;69:162-9.

[8] Li W. High-solid anaerobic codigestion of horse manure and grass in batch and semi-continuous systems. Energ Fuel 2016;30(8):6419-24.

[9] National Development and Reform Commission. The national key energy-saving low-carbon technology promotion catalogue (2017 version, low carbon section). Beijing, 2017. Available at: http://www.gov.cn/xinwen/2017-04/01/5182743/files/2bd3969838834328971fdb 44a44f698d.pdf

[10] Pan ZH, Chan WP, Veksha A, Giannis A, Dou XM, Wang HM, Lisak G, Lim T. Thermodynamic analyses of synthetic natural gas production via municipal solid waste gasification, high-temperature water electrolysis and methanation. Energy Convers Manage 2019;202:112160.

[11] Balafkandeh S, Zare V, Gholamian E. Multi-objective optimization of a tri-generation system based on biomass gasification/digestion combined with S-CO2 cycle and absorption chiller. Energy Convers Manage 2019;200:112057.

[12] Rosner F, Chen Q, Rao A, Samuelsen S. Thermo-economic analyses of concepts for increasing carbon capture in high-methane syngas integrated gasification combined cycle power plants. Energy Convers Manage 2019;199:112020.

[13] Yao Z, Li W, Kan X, Dai Y, Tong, YW, Wang C. Anaerobic digestion and gasification hybrid system for potential energy recovery from yard waste and woody biomass. Energy 2017;124:133-45.

[14] Hu M, Gao L, Chen Z, Ma C, Zhou Y, Chen J, Ma S, Laghari M, Xiao B, Zhang B, Guo D. Syngas production by catalytic in-situ steam co-gasification of wet sewage sludge and pine sawdust. Energy Convers Manage 2016;111:409-16.

[15] Xu T, Bhattacharya S. Direct and two-step gasification behaviour of Victorian brown coals in an entrained flow reactor. Energy Convers Manage 2019;195:1044-55.

[16] Wang Y, Tang Y, Guo X, Xie Q, Finkelman RB, Li P, Chen P. Fate of potentially hazardous trace elements during the entrained-flow coal gasification processes in China. Sci Total Environ 2019;668:854-66.

[17] BP. BP energy outlook. Country insight-China; 2018.

[18] Nsaful F, Görgens JF, Knoetze JH. Comparison of combustion and pyrolysis for energy generation in a sugarcane mill. Energy Convers Manage 2013;74:524-34.

[19] Jayaraman K, Gökalp I. Pyrolysis, combustion and gasification characteristics of miscanthus and sewage sludge. Energy Convers Manage 2015;89:83-91.

[20] Thengane SK, Gupta A, Mahajani SM. Co-gasification of high ash biomass and high ash coal in downdraft gasifier. Bioresour Technol 2019;273:159-68.

[21] Wu Z, Meng H, Luo Z, Chen L, Zhao J, Wang S. Performance evaluation on co-gasification of bituminous coal and wheat straw in entrained flow gasification system. Int J Hydrogen Energ 2017;42(30):18884-93.

[22] Chang S, Zhang Z, Cao L, Ma L, Wang F, Li J, Li W. Interaction and kinetics study of the co-gasification of high-solid anaerobic digestate and lignite. Molecules 2020;25:459.

[23] Hayashi J, Kudo S, Kim H, Norinaga K, Matsuoka K, Hosokai S. Low-temperature gasification of biomass and lignite: consideration of key thermochemical phenomena, rearrangement of reactions, and reactor 
configuration. Energ Fuel 2014;28:4-21.

[24] Cortazar M, Alvarez J, Lopez G, Amutio M, Santamaria L, Bilbao J, Olazar M. Role of temperature on gasification performance and tar composition in a fountain enhanced conical spouted bed reactor. Energy Convers Manage 2018;171:1589-97.

[25] Widjaya ER, Chen G, Bowtell L, Hills C. Gasification of non-woody biomass: A literature review. Renew Sust Energ Rev 2018;89:184-93.

[26] Collot AG, Zhuo Y, Dugwell DR, Kandiyoti R. Co-pyrolysis and co-gasification of coal and biomass in bench-scale fixed-bed and fluidised bed reactors. Fuel 1999;78(6):667-79.

[27] Lv P, Xiong Z, Chang J, Wu C, Chen Y, Zhu J. An experimental study on biomass air-steam gasification in a fluidized bed. Bioresour Technol 2004;95:95-101.

[28] Zhang D. Study on co-pyrolysis and gasification characteristics of distillers' grains and coal. Master thesis. Guizhou University. Guiyang. 2016.

[29] Pio D, Tarelho L, Tavares A, Matos M, Silva V. Co-gasification of refused derived fuel and biomass in a pilot-scale bubbling fluidized bed reactor. Energy Convers Manage 2020;206:112476.

[30] Li X, Hayashi J, Li C. FT-Raman spectroscopic study of the evolution of char structure during the pyrolysis of a Victorian brown coal. Fuel 2006;85(12):1700-07.

[31] Mosqueda A, Wei J, Medrano K, Gonzales H, Ding L, Yu G, Yoshikawa K. Co-gasification reactivity and synergy of banana residue hydrochar and anthracite coal blends. Appl Energy 2019;250:92-7.

[32] $\mathrm{Fu} \mathrm{P}, \mathrm{Hu} \mathrm{S}$, Xiang J, Sun L, Su S, Wang J. Evaluation of the porous structure development of chars from pyrolysis of rice straw: Effects of pyrolysis temperature and heating rate. J Anal Appl Pyrol 2012;98:177-83.

[33] Avnir D, Jaroniec, M. An isotherm equation for adsorption on fractal surfaces of heterogeneous porous materials. Langmuir 1989;5(6):1431-3.

[34] Jaroniec M. Evaluation of the fractal dimension from a single adsorption-isotherm. Langmuir 1995;11(6):2316-17.

[35] Wang Z, Burra K G, Lei T, Gupta A. Co-gasification characteristics of waste tire and pine bark mixtures in CO2 atmosphere. Fuel 2019;257:116025.

[36] Saha P, Helal U, Toufiq R. A steady-state equilibrium-based carbon dioxide gasification simulation model for hydrothermally carbonized cow manure. Energy Convers Manage 2019;191:12-22.

[37] Cantelo R. The thermal decomposition of methane. J Chem Phys 1924;28:1036-48.

[38] Xu C, Hu S, Xiang J, Zhang L, Sun L, Shuai C, Chen Q, He L, Edreis EMA. Interaction and kinetic analysis for coal and biomass co-gasification by TG-FTIR. Bioresour Technol 2014; 154:313-21.s

[39] Kan X, Chen XP, Shen Y, Alexei A L, Kraft M, Wang C H. Box-Behnken design based $\mathrm{CO} 2$ co-gasification of horticultural waste and sewage sludge with addition of ash from waste as catalyst, Appl Energ 2019;242:1549-1561.

[40] You SM, Wang W, Dai YJ, Tong YW, Wang CH. Comparison of the co-gasification of sewage sludge and food wastes and cost-benefit analysis of gasification- and incineration-based waste treatment schemes. Bioresour Technol 2016;218:595-605.

[41] Xu C. Study on reaction mechanism and its performance of coal and biomass co-gasification with steam. Doctoral Thesis. Huazhong University of science and technology. Wuhan. 2014. 
[42] Li W, Wu S, Wu Y, Huang S, Gao J. Gasification characteristics of biomass at a high-temperature steam atmosphere. Fuel Process Technol 2019;194:106090.

[43] Ping C, Zhou J, Cheng J, Yang W, Cen K. Surface structure of blended coals during pyrolysis (in Chinese). J Chem Ind Eng (China) 2007;58(7):1793-9.

[44] Lu Y, Deng Z. Practical infrared spectrum analysis (in Chinese). Beijing, 1989.

[45] Antonov EN, Bagratashvili VN, Popov VK, Sobol EN, Howdle SM. Determination of the stability of laser deposited apatite coatings in phosphate buffered saline solution using Fourier transform infrared (FTIR) spectroscopy. Spectrochim Acta A 1996;52(1):123-7.

[46] Lim SC, Vaughey JT, Harrison WTA, Dussack LL, Jacobson AJ, Johnson JW. Redox transformations of simple vanadium phosphates: the synthesis of $\epsilon-\mathrm{VOPO}_{4}$. Solid State Ionics 1996;84(3):219-26.

[47] Viala S, Freche M, Lacout JL. Effect of chitosan on octacalcium phosphate crystal growth. Carbohyd Polym 1996;29(3):197-201.

[48] Shanghai Institute of Organic Chemistry of CAS. Chemistry Database. Available at: http://www.organchem.csdb.cn.[1978-2019]

[49] Chen Y, Yang H, Wang X, Zhang S, Chen H. Biomass-based pyrolytic polygeneration system on cotton stalk pyrolysis: Influence of temperature. Bioresour Technol 2012;107:411-8.

[50] Xu M, Wu Y, Nan D, Lu Q, Yang Y. Effects of gaseous agents on the evolution of char physical and chemical structures during biomass gasification. Bioresour Technol 2019;292:121994.

[51] Hu J, Chen Y, Qian K, Yang Z, Yang H, Li Y, Chen H. Evolution of char structure during mengdong coal pyrolysis: Influence of temperature and $\mathrm{K}_{2} \mathrm{CO}_{3}$. Fuel Process Technol 2017;159:178-86.

[52] Zhang K, Li Y, Wang Z, Li Q, Whiddon R, He Y, Cen K. Pyrolysis behavior of a typical Chinese sub-bituminous Zhundong coal from moderate to high temperatures. Fuel 2016;185:701-8.

[53] Asadullah M, Zhang S, Min Z, Yimsiri P, Li C. Effects of biomass char structure on its gasification reactivity. Bioresour Technol 2010;101 (20):7935-43.

[54] Guo X, Tay HL, Zhang S, Li C. Changes in char structure during the gasification of a victorian brown coal in steam and oxygen at $800{ }^{\circ} \mathrm{C}$. Energ Fuel 2008;22(6):4034-8.

[55] Yu J, Sun L, Berrueco C, Fidalgo B, Paterson N, Millan M. Influence of temperature and particle size on structural characteristics of chars from Beechwood pyrolysis. J Anal Appl Pyrol 2018;130:127-34.

[56] Ito O. Diffuse reflectance spectra of coals in the UV-visible and near-IR regions. Energ Fuel 1992;6(5):662-5.

[57] Li C. Some recent advances in the understanding of the pyrolysis and gasification behaviour of Victorian brown coal. Fuel 2007;86(12):1664-83.

[58] Lin D, Liu L, Zhao Y, Zhaso Y, Qiu P, Xie X, Sun S. Physicochemical structure characteristics and intrinsic reactivity of demineralized coal char rapidly pyrolyzed at elevated pressure. J Energy Inst 2019. In press.

[59] $\mathrm{Hu}$ J, Shao J, Yang H, Lin G, Chen Y, Wang X, Zhang W, Chen H. Co-gasification of coal and biomass: Synergy, characterization and reactivity of the residual char. Bioresour Technol 2017;244:1-7.

[60] Xu S, Zeng X, Han Z, Cheng J, Wu R, Chen Z, Masěk O, Fan X, Xu G. Quick pyrolysis of a massive coal sample via rapid infrared heating. Appl Energy 2019;242:732-40.

[61] Xu S. Coal pyrolysis for oil and gas with infarared quick heating and staged 
reaction control. Doctoral thesis. Chinese Academy of Sciences. Beijing. 2019.

[62] Guo F, Jia X, Liang S, Zhou N, Chen P, Ruan R. Catalytic cracking of biomass pyrolysis tar over char-supported catalysts. Energy Convers Manage 2018;167:81-90.

716

717

718

[63] Zeng X, Wang F, Li H, et al. Pilot verification of a low-tar two-stage coal gasification process with a fluidized bed pyrolyzer and fixed bed gasifier. Appl Energy 2014;115:9-16. 